Original Research

\title{
The competency of Indonesian pharmacy students in handling a self-medication request for a cough:
} a simulated patient study

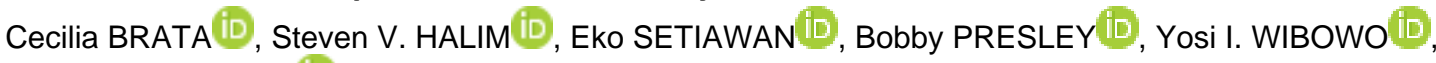 \\ Carl R. SCHNEIDER (D). \\ Received (first version): 2-Jan-2021 \\ Accepted: 11-Apr-2021 \\ Published online: 28-Apr-202
}

\begin{abstract}
Background: Cough is a common symptom for which people frequently present to community pharmacies. Previous articles from developing countries have shown that the provision of self-medication consultation for cough in community pharmacies were suboptimal, with knowledge deficiency being a contributing factor. However, little is known regarding the ability of pharmacy students in handling self-medication consultations in developing countries.

Objectives: To measure the competency of Indonesian pharmacy students in providing self-medication consultations for patients with chronic cough and to identify factors associated with the provision of appropriate advice.

Method: This study is a cross-sectional study. A simulated patient method using a product and a symptom-based request of chronic cough was used in students from a pharmacy school in Indonesia. The nature and amount of information gathered and advice provided by pharmacy students were noted and audio-recorded. A logistic regression analysis was performed to identify factors associated with the provision of appropriate advice.

Results: The information gathered by participating students was not comprehensive. The most common types of information gathered were related to the nature and duration of the cough. Information relating to accompanying symptoms, medications, and allergies was gathered in less than $60 \%$ of the participating students for both product and symptom based scenarios. The appropriate advice of direct medical referral was provided in $54 \%$ and $56 \%$ of the 183 participating students for the product and symptom-based request scenarios respectively. Asking about symptom duration and prior medical conditions were positively associated with the provision of appropriate advice in the symptom and product based requests respectively.

Conclusion: Student competency in self-medication consultation for chronic cough needs to be improved. Appropriate informationgathering is a predictor of appropriate advice. Further qualitative research identifying factors affecting students' competence in providing self-medication consultation is required, so that suitable interventions are developed and implemented.
\end{abstract}

\section{Keywords}

Cough; Antitussive Agents; Self Medication; Referral and Consultation; Students, Pharmacy; Pharmacists; Patient Simulation; Logistic Models; Multivariate Analysis; Indonesia

\section{INTRODUCTION}

Cough, a respiratory reflex to clear the upper airways, is a common condition that affects people worldwide. ${ }^{1-3}$ Based on the duration, cough can be categorised as acute, subacute and chronic. ${ }^{4}$ Acute cough is defined as having a duration of less than three weeks and is commonly caused by upper respiratory tract infections and acute bronchitis. ${ }^{4,5}$ Sub-acute cough usually lasts between three to eight weeks

Cecilia BRATA. PhD. Lecturer. Centre of Medicine Information and Pharmaceutical Care, Faculty of Pharmacy, University of Surabaya. Surabaya (Indonesia). cecilia.brata@gmail.com

Steven Victoria HALIM. Mpharm. Lecturer. Centre of Medicine Information and Pharmaceutical Care, Faculty of Pharmacy,

University of Surabaya. Surabaya (Indonesia).

stevenvictoria@staff.ubaya.ac.id

Eko SETIAWAN. MSc (Clin Pharm). Lecturer. Centre of Medicine Information and Pharmaceutical Care, Faculty of Pharmacy, University of Surabaya. Surabaya (Indonesia)

ekosetiawan.apt@gmail.com

Bobby PRESLEY. Mpharm. Lecturer. Centre of Medicine Information and Pharmaceutical Care, Faculty of Pharmacy, University of Surabaya. Surabaya (Indonesia).

bobbypresley@staff.ubaya.ac.id

Yosi Irawati WIBOWO. PhD. Senior Lecturer. Centre of Medicine Information and Pharmaceutical Care, Faculty of Pharmacy, University of Surabaya. Surabaya (Indonesia).

yosi wibowo@staff.ubaya.ac.id

Carl R. SCHNEIDER. PhD. Senior Lecturer. School of Pharmacy,

Faculty of Medicine and Health, University of Sydney. Sydney

(Australia).carl.schneider@sydney.edu.au and is most commonly due to post infectious cough or exacerbation of underlying disease, such as upper airways cough syndrome (UACS), asthma and other pulmonary diseases. ${ }^{4}$ Meanwhile, chronic cough is defined as cough lasting longer than eight weeks and can be attributed to bacterial infection such as Mycobacterium tuberculosis infections, environmental exposure such as tobacco smoke and air pollutants, adverse drug reactions to certain medications such as Angiotensin Converting Enzyme (ACE) inhibitors or Angiotensin Receptor Blockers (ARBs), and underlying medical conditions, including asthma and other pulmonary diseases, gastro-oesophageal reflux disease, upper airway cough syndrome, and cardiac origins. ${ }^{4,6}$

Many patients with cough often self-medicate to alleviate their symptoms, with community pharmacies as wellknown sources for medicine supply that are accessible to most patients. ${ }^{7-10}$ Self-medication in this paper refers to the use of medicines by people on their own initiative, without prescription by a medical doctor. ${ }^{11,12}$ Surveys have shown that cough medicines are one of the highest selling over the counter (OTC) product categories in community pharmacies in many countries. ${ }^{13,14}$ This situation emphasises the importance of the role of community pharmacists. ${ }^{9}$ They are health care professionals who are well positioned in the community to provide professional advice for patients with cough. 
In general, the provision of pharmaceutical consultation in community pharmacies include two important steps, which are: patient assessment and the provision of advice. ${ }^{15-17}$ During patient assessment, pharmacists should gather relevant information, such as information on patient identity, symptoms (such as nature and duration of the symptoms, accompanying symptoms, etc.), action that has been taken to alleviate the symptoms, medical conditions, current medications used, and allergies. ${ }^{18}$ Then, pharmacists need to use their knowledge to analyse the information gathered to decide what best advice that can be provided to patients. This could be medical referral, recommended products along with the product information, provided non-pharmacological advice, or other advice that are relevant to patient symptoms. ${ }^{17,19}$

Internationally, the provision of pharmaceutical consultations for patients with cough in community pharmacies is suboptimal, including Indonesia. ${ }^{20-22}$ There are deficiencies in many aspects of pharmaceutical counselling for cough, including lack of history taking and inappropriate advice provision. ${ }^{20-22}$ In developing countries, studies have identified several factors contributing to these deficiencies. $^{23-25}$ In Indonesia, previous research has identified three main factors influencing pharmaceutical consultation performance: pharmacy staff-patient interaction, the organisational context of the pharmacy, and the external pharmacy environment (Figure 1). ${ }^{23}$ These factors are complex and inter-related; for example the lack of knowledge and competency of pharmacy staff to provide quality consultation are influenced by deficiencies in pharmacy education with respect to management and pharmaceutical consultation for self-medication. ${ }^{23}$ Indonesian pharmacists also perceive that there is a problem with relevancy between what is taught in their pharmacy education and the knowledge required for practice, and therefore they felt that their knowledge is insufficient to provide optimal self-medication services. ${ }^{23,26}$ Similar findings have been reported in the literature from other developing countries, such as Brazil and Vietnam. ${ }^{24,27}$

In Indonesia, to become a pharmacist, students are required to complete a four-year Bachelor of Pharmacy (BPharm) degree, followed by a one-year pre-registration training programme (Apothecary programme). Pharmacy curricula are regulated by the Ministry of Education and are typically based on the curriculum developed by the Indonesian Association of Higher Education of Pharmacy (Assosiasi Perguruan Tinggi Farmasi Indonesia, or APTFI). ${ }^{28}$ While each pharmacy school has the freedom to design their own curriculum, APTFI suggests that the courses or units of study within the BPharm curriculum are designed to be predominantly theory based, with the addition of laboratory practice or simulation, whereas the apothecary program focuses on applied pharmacy practice. ${ }^{28}$

The quality of Indonesian pharmacy education varies widely across institutions. ${ }^{28}$ Therefore, from 2018 onwards, students in the apothecary programme are required to pass

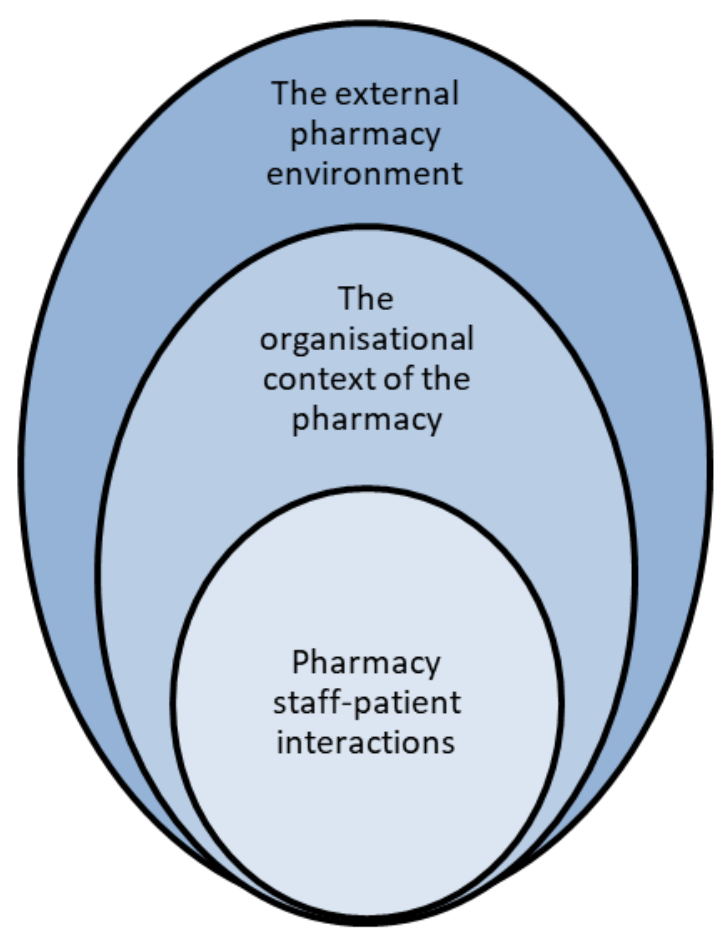

Pharmacy staff-patient interactions:

Patients' response

Patients' awareness of the role of and trust in pharmacy staff

Types of patients' requests

Patients' cultural characteristics

The professionalism of pharmacy staff

Knowledge and competence

Ability to focus on the pharmacy job

Availability and implementation of standard operating procedure

The organisational context of the pharmacy

Availability of trained staff

Availability of time to provide consultations

Staff affordability

Availability of facilities to provide consultation - counselling space

Dual employment - leading to potential conflicts of interest.

\section{The external pharmacy environment}

The number of trained pharmacy staff in the research setting Relevance of pharmacy education to the needs of pharmacy practice

Support from the Indonesian Pharmacists Association

A competitive business environment

The policy environment

Figure 1. Factors related to the provision of self-medication consultation in community pharmacies in eastern Indonesia from Brata et al. 23 
a national, computer-based test (CBT) examination before they can be registered as pharmacists. ${ }^{29}$ In addition, students also need to take an objective structured clinical examination (OSCE) as a formative assessment. ${ }^{29}$ The OSCE is intended to become a summative barrier examination; however, the transition is currently postponed as a result of the COVID pandemic.

Studies looking at the situation of Indonesian pharmacy education are limited. A study conducted at the University of Gadjah Mada, has evaluated their 422 apothecary students' performance using an OSCE. ${ }^{30}$ The authors reported that approximately $85 \%$ of the 422 students were able to pass the minor ailment station. ${ }^{30}$ However, the study aim was to measure students' experience and perception of the OSCE and not to measure the competence of students in responding to patients with minor illness.

This study is conducted to measure the competency of Indonesian pharmacy students in providing self-medication consultations for patients with a cough. In this study, the competency of pharmacy students in providing selfmedication consultation is defined as a combination of students asking/gathering essential information such as information related to patient identity, symptoms (nature, duration, action taken to alleviate symptoms, associated symptoms, etc.), medical conditions, medications used, and allergies during patient assessment and students subsequently providing appropriate advice to the patient. Therefore, the specific objectives are to: (1) describe the type and amount of information gathered; (2) describe the type and amount of advice provided, (3) measure the overall proportion of students providing appropriate advice, and (4) identify factors associated with the provision of appropriate advice.

\section{METHODS}

\section{Ethics approval}

Ethics approval was sought from the Ethical Committee University of Surabaya, Indonesia (No 057/KE/XII/2018). To protect the identity of the research setting and student participants, any identifying information was not allowed to be published.

\section{Research context}

In this particular university, topics related to selfmedication services are provided to third year BPharm students. The course (COMM PHARM 1) comprises a 4 hour session per week, consisting of a 1-hour lecture and 3hours of laboratory practice for 14 weeks. In the laboratory practice component, students are expected to be able to respond to a simulated patient (i.e., tutors or students acting as a patient) requesting self-medication for several minor ailments such as painful conditions, respiratory problems, gastrointestinal tract problems, skin problems, and eye and ear problems. The COMM PHARM 1 course is intended to provide competency in the provision of advice when responding to minor ailment requests to the level that supervised provision of advice to the public is subsequently able to be conducted in the apothecary programme.

\section{Participant recruitment}

All third year pharmacy students in the research site who had completed COMM PHARM 1 were eligible for recruitment. In the first week of semester 6 , the researchers announced and explained the study to all enrolled students in COMM PHARM 2. Announcement was made in the COMM PHARM 2 class because this is the subsequent class that needs to be enrolled after third year students completing COMM PHARM 1. Several students who had completed COMM PHARM 1 but did not enrol in COMM PHARM 2, identified via the school data register, were also contacted separately. Students were asked to participate in a simulated patient assessment at a time that suited them. Free cakes/pastry/snacks were provided after participation and an extra-curricular student point which can be printed on their non-academic transcript upon graduation was also offered. Participation was voluntary with students who agreed to participate providing informed consent.

\section{Study instrument}

This study is a cross-sectional study. A simulated patient method was used to present the scenario of cough due to worsening of asthma. The scenario was adapted from Schneider et.al and was presented as both a product and symptom-based request (Online appendix). ${ }^{21}$ The data collection form was adapted from previous literature and consisted of a checklist of participants' characteristics, the type of information gathered and the advice provided. ${ }^{15,17}$ The types of information gathered included important information that needs to be gathered in patients with cough as stated by Blenkinsopp et al. ${ }^{16}$ The information elements comprised: patient identity, symptoms (including nature of cough, duration of cough, and accompanying symptoms including danger symptoms), action taken, medical conditions, medications used, and allergies. The types of advice provided were categorised as medical referral, recommending products, recommending nonpharmacological advice or other advice (including advice on follow up). ${ }^{17}$ As per previous literature, the appropriateness of the advice for this scenario was defined as direct medical referral. ${ }^{21}$ In order to adjust to the local context, four Indonesian academics and practitioners in pharmacy practice assessed the scenario for content validity and reviewed the data collection form. No significant changes were made in the scenario and the data collection form after being revalidated.

Seven simulated patients, consisting of two pharmacists who were $\mathrm{PhD}$ students, three recent pharmacist graduates, and two drug information pharmacists were recruited and trained beforehand. The training consisted of explanation of the scenarios, how to fill the data collection form, and role plays. Role plays were repeated until the simulated patients were deemed able to accurately enact the scenarios and fill in the data collection form as evaluated by the principal researcher (CB). Details of the characteristics of the simulated patients as well as the training is presented in Online appendix and is informed by an article by Resende et al. ${ }^{31}$ 


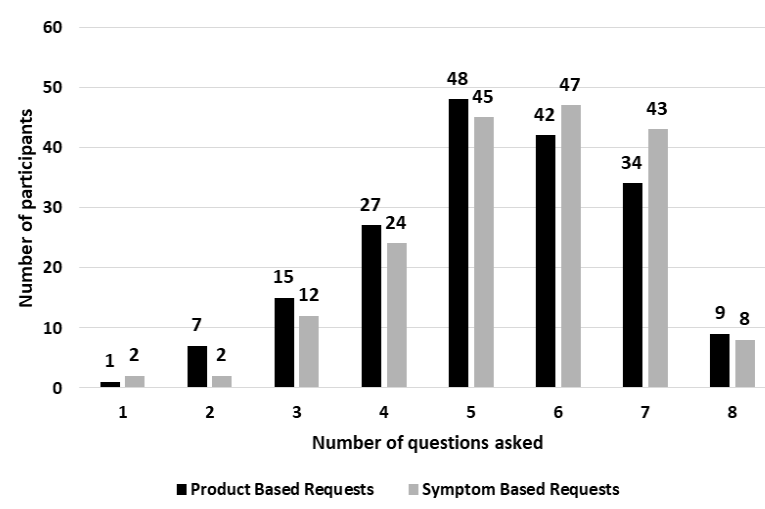

Figure 2. The number of questions asked by students

Fifteen and 23 of these 102 students also recommended cough medicines and non-pharmacological/follow up advice, respectively.

Appropriate advice, which was defined as advice that contained direct medical referral, was provided in 99 (54\%), and $102(56 \%)$ of 183 participating students in the productbased requests and symptom-based requests, respectively.

From the univariate analysis, significant variables for providing appropriate advice comprised of asking about action taken and duration of cough in the product-based request scenario (Table 4). Meanwhile, significant variables for providing appropriate advice in the symptom-based request scenario consisted of: GPA, number of questions asked, asking about duration of cough, action taken, and other medical conditions (Table 5).

After inputting these significant variables into the multivariate analysis, we determined that the nature of the information gathering by students is associated with the provision of appropriate advice. In the product-based request scenario, students who asked about the duration of cough were more likely to provide appropriate advice than students who did not ask this question (OR $4.8,95 \% \mathrm{Cl} 1.68$ 13.57). Meanwhile, in the symptom-based request scenario, students who asked about other medical conditions were more likely to provide appropriate advice than students who did not (OR 2.1, 95\%Cl 1.05-4.19). Demographic characteristics of participating students (i.e. age, gender, previous education, have working/training experience in community pharmacies, GPA, mark for COMM PHARM 1 course) were not associated with the provision of appropriate advice.

\section{DISCUSSION}

This is the first study in Indonesia that examined the ability of pharmacy students in gathering information and providing appropriate advice for a simulated patient with chronic cough. All students participated in this study were novice learners, which describes that they just learnt about self-medication consultation during their undergraduate pharmacy curriculum.

This study indicates that the information-gathering process among students in this school, needs to be improved. The lecture notes and laboratory practice module of COMMPHARM1 class indicated that topics related to informationgathering have been provided. However, this study showed that students did not gather appropriate information when encountering our simulated patients. Important information such as medical conditions, medications used, and accompanying symptoms that are needed to enable students to identify the root of the problems were asked in $40 \%$ to $75 \%$ of the encounters. This contrasts with the results from an Australian study, in which most of their novice students perform well during the informationgathering process. ${ }^{32}$ While it is argued that complete information is not always necessary to be gathered in order to provide appropriate advice, it is safer for novice students to gather complete information for assessing patients correctly and hence appropriate advice. ${ }^{33}$

In this case, advice was considered appropriate when students recommended direct medical referral. However, in both scenarios, only about $55 \%$ of them were able to do so. This figure is about similar to findings from an Australian study, which stated that appropriate advice was provided in $52 \%$ of their novice students in the case of childhood fever. ${ }^{32}$ Other than incomplete information gathered as explained above, these participating students

\begin{tabular}{|c|c|c|}
\hline The types of advice provided & $\begin{array}{l}\text { Symptom based requests } \\
n=183(\%)\end{array}$ & $\begin{array}{l}\text { Product based requests } \\
n=183(\%)\end{array}$ \\
\hline (1) Direct medical referral & $68(37 \%)$ & $61(33 \%)$ \\
\hline (1) Direct medical referral and (2) suggesting medicines* & $11(6 \%)$ & $12(7 \%)$ \\
\hline $\begin{array}{l}\text { (1) Direct medical referral, (2) suggesting medicines, and (3) suggesting non- } \\
\text { pharmacological advice or other advice.** }\end{array}$ & $5(3 \%)$ & $9(5 \%)$ \\
\hline $\begin{array}{l}\text { (1) Direct medical referral and (3) suggesting non-pharmacological advice, or } \\
\text { other advice }\end{array}$ & $18(10 \%)$ & $17(9 \%)$ \\
\hline (2) Suggesting medicines. & $29(16 \%)$ & $29(16 \%)$ \\
\hline $\begin{array}{l}\text { (2) Suggesting medicines and (3) suggesting non-pharmacological advice, or } \\
\text { other advice. }\end{array}$ & $41(22 \%)$ & $47(26 \%)$ \\
\hline (3) Suggesting non-pharmacological advice or other advice. & $1(0 \%)$ & $4(2 \%)$ \\
\hline (4) No advice suggested. $* * *$ & $10(6 \%)$ & $4(2 \%)$ \\
\hline \multicolumn{3}{|c|}{$\begin{array}{l}\text { *Medicines suggested was a variety of cough medicine brand names. } \\
\text { **Examples of non-pharmacological advice or other advice including: enough rest, eat healthy food, drink a lot of water, avoid strenuous } \\
\text { exercise, avoid dusty or unhygienic places, drink herbal medicines such as ginger and honey, and advising on follow up (such as go to a doctor } \\
\text { if there is no improvement after tyring the suggested medicines, go back to the pharmacist if there is no improvement after trying the } \\
\text { suggested medicines). } \\
* * * \text { No advice suggested meant that the students said that they did not know the answer or said that they did not know how to respond to the } \\
\text { scenario in the simulated patient test. }\end{array}$} \\
\hline
\end{tabular}


Brata C, Halim SV, Setiawan E, Presley B, Wibowo YI, Schneider CR. The competency of Indonesian pharmacy students in handling a self-medication request for a cough: a simulated patient study. Pharmacy Practice 2021 Apr-Jun;19(2):2269.

\begin{tabular}{|c|c|c|}
\hline \multirow{2}{*}{ Factors } & \multicolumn{2}{|c|}{ Univariate analysis } \\
\hline & OR (95\%Cl) & p-value \\
\hline Age & $0.95(0.696,1.286)$ & 0.723 \\
\hline $\begin{array}{r}\text { Male } \\
\text { Female }\end{array}$ & $\begin{array}{c}1.00(0.424,2.374) \\
\text { Reference }^{\wedge}\end{array}$ & 0.994 \\
\hline $\begin{array}{r}\text { High school } \\
\text { Pharmacy assistant school }\end{array}$ & $\begin{array}{c}1.27(0.682,2.376) \\
\text { Reference }\end{array}$ & 0.449 \\
\hline $\begin{array}{r}\text { Have any experience in working or training in community pharmacies } \\
\text { Yes } \\
\text { No }\end{array}$ & $\begin{array}{c}0.88(0.465,1.663) \\
\text { Reference }\end{array}$ & 0.693 \\
\hline GPA & $1.42(0.810,2.480)$ & 0.222 \\
\hline Mark for COMM PHARM 1 course & $\begin{array}{c}0.71(0.118,4.319) \\
0.86(0.228,3.224) \\
0.49(0.131,1.873) \\
0.69(0.168,2.799) \\
\text { Reference }\end{array}$ & $\begin{array}{l}0.654 \\
0.820 \\
0.290 \\
0.599\end{array}$ \\
\hline Number of questions asked & $1.16(0.955,1.417)$ & 0.132 \\
\hline Asking who is the patient & $\begin{array}{c}0.93(0.447,1.934) \\
\text { Reference } \\
\end{array}$ & 0.845 \\
\hline Asking nature of cough & $\begin{array}{c}1.10(0.474,2.566) \\
\text { Reference }\end{array}$ & 0.821 \\
\hline Asking duration of cough & $\begin{array}{c}4.77(1.677,13.566) \\
\text { Reference }\end{array}$ & $0.003^{*}$ \\
\hline Asking accompanying symptoms & $\begin{array}{c}0.78(0.435,1.408) \\
\text { Reference }\end{array}$ & 0.413 \\
\hline Asking action taken & $\begin{array}{c}0.47(0.250,0.887) \\
\text { Reference }\end{array}$ & $0.020 *$ \\
\hline Asking medications & $\begin{array}{c}1.40(0.778,2.500) \\
\text { Reference }\end{array}$ & 0.264 \\
\hline Asking medical conditions & $\begin{array}{c}1.29(0.701,2.370) \\
\text { Reference }\end{array}$ & 0.415 \\
\hline Asking allergies & $\begin{array}{c}0.75(0.417,1.338) \\
\text { Reference }\end{array}$ & 0.326 \\
\hline
\end{tabular}

may also have limited knowledge of disease and therapy and inability to analyse the information gathered; and hence inappropriate advice. ${ }^{17,32}$ The syllabus in this pharmacy school shows that during semester 1 to 4 , students only learn about basic sciences (human anatomy \& physiology, pathophysiology, and pharmacology). Topics related to diseases and drug therapy, drug related problems, and patient counselling are provided in semester 5 and above. It could be that these students may not know that the case is cough due to worsening of asthma since they haven't learnt much about asthma, and therefore they did not know that direct medical referral was needed.

A potential factor to sub-optimal student performance is the teacher-student ratio. A review of the COMM PHARM1 classroom student list and tutor schedule identified that the teacher-student ratio was 1:20 during laboratory practices and 1:80 during lectures. Such ratios may be insufficient for students to receive adequate supervised practice and feedback during simulated role-plays. As the effectiveness of simulation learning relies on practice and feedback for each learner, measures should be undertaken to optimised the teacher-student ratio. ${ }^{34}$ Furthermore, with the current curriculum design, students are expected to be ready for supervised provision of minor ailment care to the public in the apothecary programme after completing the COMM PHARM1 course. This indicates that this one semester course carries a lot of weight in the curriculum. Redesigning the BPharm curriculum, such as by adopting the spiral curriculum in which key concepts are revisited and reinforced throughout the curriculum with increasing levels of complexity, could be more appropriate than a stand-alone course. ${ }^{35,36}$ Further qualitative research looking at the design of the current curriculum, students and teachers' perceptions, the teaching-learning process including the mode of delivery is required for designing interventions for the optimisation of student performance.

Simulated patient technique has been used widely in pharmacy education, including for training in consultation for self-medication requests. ${ }^{34}$ Using simulated patient technique as an educational tool may improve training 
Brata C, Halim SV, Setiawan E, Presley B, Wibowo YI, Schneider CR. The competency of Indonesian pharmacy students in handling a self-medication request for a cough: a simulated patient study. Pharmacy Practice 2021 Apr-Jun;19(2):2269.

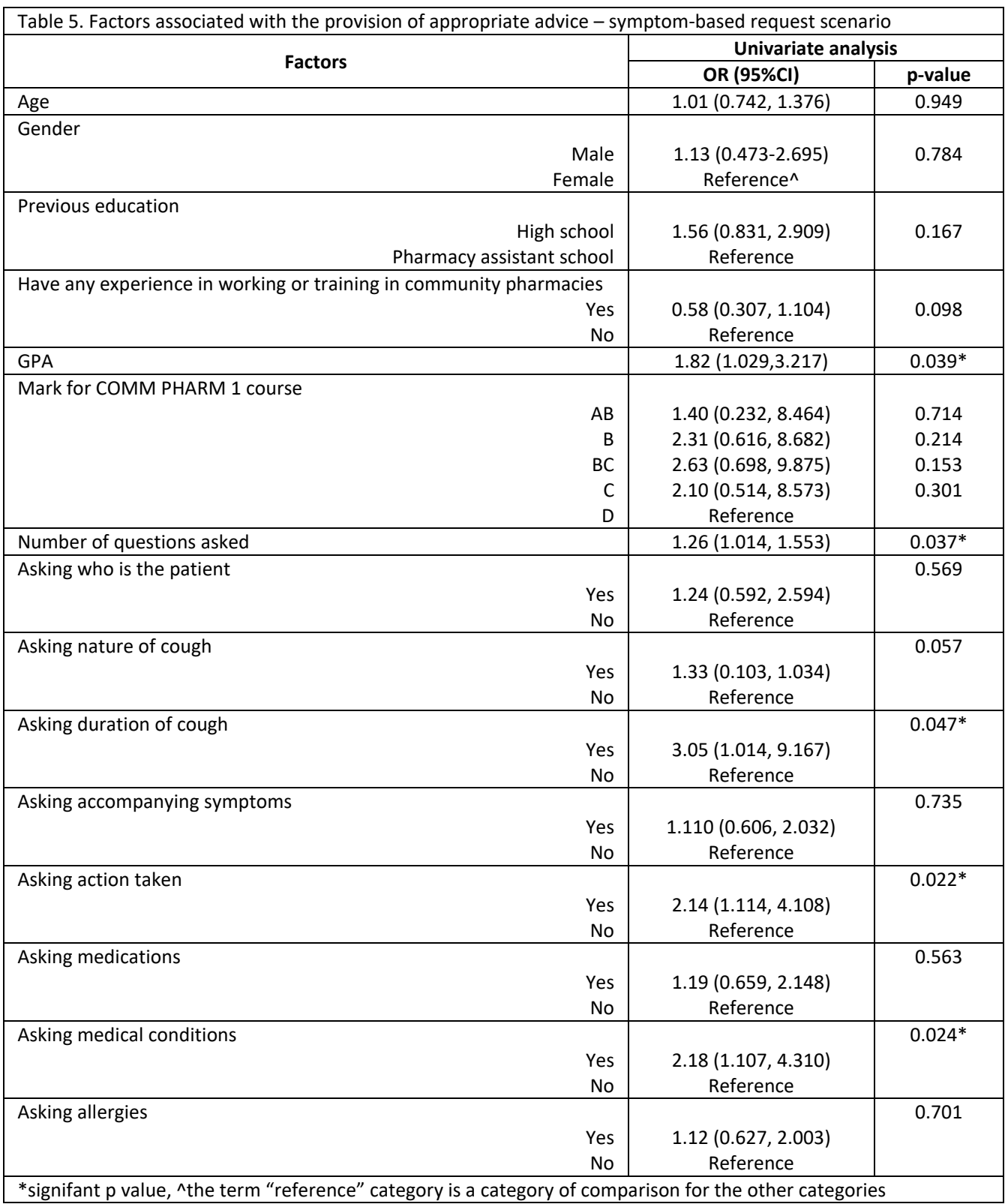

since it can reinforce knowledge, integrate between knowledge and practice, and improve professional skills and attitudes (e.g., communication skills, decision making, emphaty, teamwork, social and cultural competency, and confidence). $^{34,37}$ In addition as an educational tool, simulated patient technique can also be an assessment tool for evaluating the effectiveness of the training provided. Indeed, simulated patients in the form of OSCE is planned to be a compulsory element of the Indonesian national pharmacist registration examination. ${ }^{30}$ Evidence suggests that examinations using simulated patient technique challenges students to think critically and indicates student performance in real clinical encounters. ${ }^{37}$ Indonesian pharmacy schools, therefore, should use this technique in the teaching and evaluation of pharmacy students.

The multivariate analysis identified that asking a particular type of question (i.e., duration of cough and medical conditions) are factors positively associated with the provision of appropriate advice (Tables 4 and 5). This finding is in keeping with a previous Australian study in pharmacy staff responding to a very similar scenario. ${ }^{21}$ It could be that by asking such questions, students were able to discern that the patient had a contraindication for selfmedication and recommend medical referral. It is important to train students to be able to ask key questions according to the clinical situation to improve the appropriateness of advice for minor ailments. Further, as there is a current lack of formal guidance on informationgathering when responding to patients with selfmedication requests in Indonesia, policy makers such as the Indonesian Pharmacists Association (IAI), the Ministry of Health, and the APTFI may need to develop and promote a national protocol to improve appropriate informationgathering and to optimise the provision of care.

Research evaluating the competence of pharmacy students providing self-medication consultation in Indonesia is limited. Kristina et.al reported that $85 \%$ of 422 apothecary students from the University of Gadjah Mada, passed the the minor ailment station in their OSCE assessment. ${ }^{30}$ However, detailed aspects assessed in this minor illness 
station were not provided in the article and the population used were different with this study's population (apothecary students vs third year students in this study); thus making direct comparison difficult. It could be hypothesized that final year/apothecary programme students may have superior outcomes compared to students at an earlier stage in their education, as found in an Australian study. ${ }^{32}$

Despite the students in this study only being halfway through their pharmacist training, their performance was superior to Indonesian pharmacy staff, as reported in previous research. ${ }^{20,38}$ When responding to a simulated patient asking for a particular product for chronic cough, all of these students conducted information gathering and $54 \%$ of them were able to provide appropriate advice. In contrast, only $1 \%$ of pharmacy staff performed information gathering and none provided appropriate advice in the previous articles. ${ }^{20,38}$ Although the cases of chronic cough used between this study and the previous studies were not exactly the same, the essence and complexity of the cases are similar; and therefore we think they can be compared.

Better performance of these students compared to pharmacy staff as reported in the previous article may be due to several reasons. As stated in the theory of the Efficiency-Thoroughness Trade-Off (the ETTO principle), there is a balance or tradeoff between being efficient and being thorough. ${ }^{39}$ If demands to productivity are high, thoroughness is usually reduced. On the other hand, if demands to safety are high, efficiency is reduced. Following this theory, it could be that pharmacy staff were being efficient due to demands of high productivity, whereas students were being thorough because they knew that they were being assessed and therefore they will try harder to show their best performance. Another possible reason of why Indonesian pharmacy staff performed more poorly than students might be that the person that typically handles patients with self-medication requests in pharmacies is a non-pharmacist, as has been reported in Indonesian and other developing countries' literature. ${ }^{40-42}$ This being the case, measures should be taken to ensure that pharmacists are able to provide self-medication services when they are on duty. Further research on why students perform better than pharmacy staff is required.

\section{Limitations}

This study was only conducted in one pharmacy school in Indonesia. Because the quality of Indonesian pharmacy schools has been reported to vary, these findings may not be generalisable for all pharmacy students in Indonesia. ${ }^{28}$ Therefore, further research using samples of different pharmacy schools are required to obtain a general picture of Indonesian pharmacy students' ability in self-medication consultation. Furthermore, the study was conducted in novice students and therefore may not reflect the ability of pharmacy graduates. Future research on evaluating the ability of final year pharmacy students in handling selfmedication consultation is also required. In addition, a Hawthorne effect may have been generated, because this is an overt method, in which participating students knew that they were being assessed. However, although these students have showed their best performance, only half of them were able to provide appropriate advice; and therefore there is still a need for improvement. Lastly, there was a possibility of selection bias in this study. However, the characteristics of the participating students were similar to the student cohort (Table 1) and therefore it might not significantly affect the findings.

\section{CONCLUSIONS}

The performance of novice students in responding appropriately to a simulated patient with a self-medication request for cough is sub-optimal. Appropriate informationgathering is a predictor of appropriate provision of advice. Measures to improve student performance, such as curriculum restructuring, optimising teacher-student ratio, and developing a protocol for appropriate informationgathering may be required. Further qualitative research to identify factors affecting student performance is required to develop strategies to improve student response to selfmedication requests.

\section{CONFLICT OF INTEREST}

None.

\section{FUNDING}

This study was carried out with the grant from The University of Surabaya Institute of Research and Community Services.

\section{AUTHOR ROLES (CRediT)}

Conceptualization: CB, YIW, ES, SV.

Data curation: $\mathrm{CB}, \mathrm{SV}$.

Formal analysis: $\mathrm{CB}$.

Funding acquisition: $\mathrm{CB}, \mathrm{SVH}$.

Investigation: $\mathrm{CB}, \mathrm{SVH}, \mathrm{YIW}, \mathrm{ES}, \mathrm{BP}$.

Methodology: $C B$.

Project administration: $\mathrm{CB}, \mathrm{SVH}$.

Resources: SVH, BP.

Supervision: $\mathrm{CB}, \mathrm{CS}$

Validation: $\mathrm{CB}, \mathrm{YIW}, \mathrm{ES}$, SV.

Visualization: $\mathrm{CS}, \mathrm{CB}$.

Writing - original draft: $\mathrm{CB}$.

Writing - review \& editing: CS, CB.

\section{References}

1. Chung KF, Pavord ID. Prevalence, pathogenesis, and causes of chronic cough. Lancet. 2008;371(9621):1364-1374 https://doi.org/10.1016/s0140-6736(08)60595-4

2. Kauffmann F, Varraso R. The epidemiology of cough. Pulm Pharmacol Ther. 2011;24(3):289-294. https://doi.org/10.1016/i.pupt.2010.10.012

3. Tietze KJ. Cough. In: Krinsky DL, Ferreri SP, Hemstreet B, et al., editors. Handbook of Nonprescription Drugs: An interactive approach to self-care. Washington DC: APhA; 2015. 
4. Irwin RS, French CL, Chang AB, Altman KW; CHEST Expert Cough Panel*. Classification of Cough as a Symptom in Adults and Management Algorithms: CHEST Guideline and Expert Panel Report. Chest. 2018;153(1):196-209. https://doi.org/10.1016/..chest.2017.10.016

5. Holzinger F, Beck S, Dini L, Stöter C, Heintze C. The diagnosis and treatment of acute cough in adults. Dtsch Arztebl Int. 2014;111(20):356-363. https://doi.org/10.3238/arztebl.2014.0356

6. Perotin JM, Launois $\mathrm{C}$, Dewolf M, et al. Managing patients with chronic cough: challenges and solutions. Ther Clin Risk Manag. 2018;14:1041-1051. https://doi.org/10.2147/tcrm.s136036

7. Limaye D, Limaye V, Krause G, Fortwengel G. A Systematic review of the literature to assess self medication practices. Ann Med Health Sci Res. 2017;7:1-15.

8. Ambizas EM. Acute cough—does anything help?. US Pharm. 2019;1:8-12.

9. Rutter P. Role of community pharmacists in patients' self-care and self-medication. Integr Pharm Res Pract. 2015;4:57-65. https://doi.org/10.2147/iprp.s70403

10. Darmanin Ellul R, Cordina M, Buhagiar A, Fenech A, Mifsud J. Health complaints and use of medicines among adolescents in Malta. Pharm Pract (Granada). 2008;6(3):165-170. https://doi.org/10.4321/s1886-36552008000300008

11. Brandt N. Self-medication. In:Gellman MD, Turner JR, editors. Encyclopedia of Behavioral Medicine. New York: Springer; 2013.

12. International Pharmaceutical Federation. Joint statement by The International Pharmaceutical Federation and The World Self-Medication Industry: Responsible self-medication. https://www.fip.org/file/1484 (accessed Feb 1, 2021).

13. The World Self-Medication Industry. Proceedings of WSMI 6th Asia Pacific Regional Conference. Beijing, $26-29$ Oct 2004.

14. Connelly D. The OTC market in Britain in 2015. Pharm J. 2016;296:7887.

15. Schneider C. Provision of non-prescription medication by community pharmacists in Western Australia. University of Western Australia; 2010.

16. Blenkinsopp A, Duerden M, Blenkinsopp J. Symptoms in the pharmacy: A guide to the management of common illnesses. Oxford: Wiley-Blackwell; 2018.

17. Brata C. The provision of self-medication consultations in community pharmacies in an Eastern Indonesian setting. University of Western Australia; 2015.

18. Brata C, Gudka S, Schneider CR, Everett A, Fisher C, Clifford RM. A review of the information-gathering process for the provision of medicines for self-medication via community pharmacies in developing countries. Res Social Adm Pharm. 2013;9(4):370-383. https://doi.org/10.1016/j.sapharm.2012.08.001

19. Krinsky DL, Ferreri SP, Hemstreet B, et al, editors. Handbook of nonprescription drugs: an interactive approach to selfcare. 18 ed. Washington DC: APhA; 2015.

20. Brata C, Schneider CR, Marjadi B, Clifford RM. The provision of advice by pharmacy staff in eastern Indonesian community pharmacies. Pharm Pract (Granada). 2019;17(2):1452. https://doi.org/10.18549/pharmpract.2019.2.1452

21. Schneider CR, Everett AW, Geelhoed E, et al. Provision of primary care to patients with chronic cough in the community pharmacy setting. Ann Pharmacother. 2011;45(3):402-408. https://doi.org/10.1345/aph.1p514

22. Mináriková $D$, Fazekaš $T$, Minárik $P$, Jurišová $E$. Assessment of patient counselling on the common cold treatment at Slovak community pharmacies using mystery shopping. Saudi Pharm J. 2019;27(4):574-583. https://doi.org/10.1016/.j.jsps.2019.02.005

23. Brata C, Fisher C, Marjadi B, Schneider CR, Clifford RM. Factors influencing the current practice of self-medication consultations in Eastern Indonesian community pharmacies: a qualitative study. BMC Health Serv Res. 2016;16:179. https://doi.org/10.1186/s12913-016-1425-3

24. Thang DX. An investigation of non-prescription medicine supply in community pharmacies in Hanoi, Vietnam. University of Nottingham; 2013

25. Halila GC, Junior EH, Otuki MF, Correr CJ. The practice of OTC counseling by community pharmacists in Parana, Brazil. Pharm Pract (Granada). 2015;13(4):597. https://doi.org/10.18549/pharmpract.2015.04.597

26. Hermansyah A, Sainsbury E, Krass I. Multiple policy approaches in improving community pharmacy practice: the case in Indonesia. BMC Health Serv Res. 2018;18(1):449. https://doi.org/10.1186/s12913-018-3258-8

27. Da Rocha CE, Bispo ML, Alcantara T, et al. What do Brazilian community pharmacists know about self-medication for minor illnesses? A pilot study in the northeast of Brazil. J Appl Pharm Sci. 2014;4(5):12-20. https://doi.org/10.7324/JAPS.2014.40503

28. Asosiasi Pendidikan Tinggi Farmasi Indonesia. [Academic manuscripts of graduate competency standards and pharmaceutical education curriculum standards]. http://www.aptfi.or.id/dokumen/2016-0101NAKompetensi\&KurAPTFI2013.pdf (accessed Dec 26, 2020).

29. Fakultas Farmasi Universitas Indonesia. [The UI pharmacist followed UKAI OSCE 2019]. https://farmasi.ui.ac.id/2019/07/apoteker-ui-mengikuti-ukai-osce-2019/ (acessed Mar 3, 2021).

30. Kristina SA, Gustriawanto N, Rokhman MR, Aditama H, Sari IP. Students' first experience with objective structured clinical examination in a pharmacy school in Indonesia. J App Pharm Sci. 2018;8(09):102-106. https://doi.org/10.7324/JAPS.2018.8915

31. Resende KA, Cavaco AM, Luna-Leite MD, et al. Training and standardization of simulated patients for multicentre studies in clinical pharmacy education. Pharm Pract (Granada). 2020;18(4):2038. https://doi.org/10.18549/pharmpract.2020.4.2038

32. Wigmore BC, Collins JC, Schneider CR, Arias D, Moles RJ. Ability of Pharmacy Students, Pharmacists and Pharmacy Support Staff to Manage Childhood Fever via Simulation. Am J Pharm Educ. 2018;82(10):6445 https://doi.org/10.5688/ajpe6445 
33. Newton GD, Divine H. Patient assessment and consultation. In: Krinsky DL FS, Hemstreet B, Hume AL, et al, editors. Handbook of Non Prescription Drugs. 18 ed. Washington: APhA; 2015.

34. Packeiser PB, Castro MS. Evaluation of simulated drug dispensing and patient counseling in the course of pharmaceutical improvement: 2009 to 2015. Pharm Pract (Granada). 2020;18(4):1865. https://doi.org/10.18549/pharmpract.2020.4.1865

35. Harden RM. What is a spiral curriculum?. Med Teach. 1999;21(2):141-143. https://doi.org/10.1080/01421599979752

36. Setiadi AP, Wibowo Y, Brata C, Halim SV, Wardhani SA, Sunderland B. The role of pharmacists in community education to promote responsible self-medication in Indonesia: an application of the spiral educational model. Int $\mathrm{J}$ Clin Pharm. 2020;42(4):1088-1096. https://doi.org/10.1007/s11096-020-01055-8

37. Smithson J, Bellingan M, Glass B, Mills J. Standardized patients in pharmacy education: An integrative literature review. Curr Pharm Teach Learn. 2015;7(6):851-863. https://doi.org/10.1016/i.cptl.2015.08.002

38. Brata C, Marjadi B, Schneider CR, Murray K, Clifford RM. Information-gathering for self-medication via Eastern Indonesian community pharmacies: a cross-sectional study. BMC Health Serv Res. 2015;15:8. https://doi.org/10.1186/s12913-014-0670-6

39. Hollnagel E. The ETTO Principle: efficiency-thoroughness trade-off. London: Ashgate; 2009. ISBN 9780754676782.

40. Puspitasari HP, Faturrohmah A, Hermansyah A. Do Indonesian community pharmacy workers respond to antibiotics requests appropriately?. Trop Med Int Health. 2011;16(7):840-846. https://doi.org/10.1111/j.1365-3156.2011.02782.x

41. Zawahir S, Lekamwasam S, Aslani P. Antibiotic dispensing practice in community pharmacies: A simulated client study. Res Social Adm Pharm. 2019;15(5):584-590. https://doi.org/10.1016/j.sapharm.2018.07.019

42. Amin M, Chewing B. Pharmacies without pharmacists: Absenteeism plagues pharmacies in developing countries. Res Soc Adm Pharm. 2017;14:400-401. http://doi.org/10.1016/i.sapharm.2016.10.013 